\title{
Ultrasound pretreatment as an alternative to improve essential oils extraction
}

\author{
Flávia Michelon Dalla Nora ${ }^{1,2}$ Caroline Dellinghausen Borges $^{1}$
}

\begin{abstract}
${ }^{1}$ Centro de Ciências Químicas, Farmacêuticas e de Alimentos, Universidade Federal de Pelotas (UFPEL), Pelotas, RS, Brasil.
${ }^{2}$ Departamento de Tecnologia e Ciência dos Alimentos, Universidade Federal de Santa Maria (UFSM), 97105-900, Santa Maria, RS, Brasil. E-mail: flavia1086@hotmail.com. Corresponding author.
\end{abstract}

\begin{abstract}
Essential oils are substances originated from plants in general. These compounds are well known to have a high biological activity, specially the antioxidant and antimicrobial. Several extraction techniques are employed to obtain these substances. However, the majority of these techniques require a long extraction time. In this sense, innovative and alternative extraction techniques, such as ultrasound, have recently been the target of studies. In view of the small amount of publications using ultrasonic pretreatment, this review aimed to congregate current relevant information on ultrasound-assisted extraction of essential oils. In this sense, theoretical aspects, such as the main factors that influence the performance of this technique as well as the advantages and disadvantages of the use of ultrasound as an environmental friendly alternative technique to improve the extraction of essential oil in comparison to traditional methods, are shown. Considering the available studies in the literature on essential oil extraction using ultrasonic pretreatment, low frequencies ranged from 20 to $50 \mathrm{kWz}$ and times ranged from 20 to $40 \mathrm{~min}$ were used. The use of ultrasonic pretreatment represents a time reduction to near $70 \%$ in relation to the conventional hydrodistillation. Also, these conditions enabled a growth in the extraction of bioactive compounds and consequently improving the antioxidant and antimicrobial activities of essential oils.
\end{abstract}

Key words: essential oil, food, extraction, ultrasound, green chemistry.

Pré-tratamento por ultrassom como alternativa para melhoria da extração de óleos essenciais

RESUMO: Óleos essenciais são substâncias originadas de plantas em geral. Estes compostos são bem conhecidos por apresentarem elevada atividade biológica, especialmente atividade antioxidante e antimicrobiana. A fim de obter estas substâncias, são utilizadas várias técnicas de extração. A maioria destas técnicas é caracterizada por requererem um elevado tempo de processo. Neste sentido, a aplicação do ultrassom como uma técnica alternativa tem sido alvo de estudos, ganhando destaque nos últimos anos. Tendo em vista a pequena quantidade de publicações utilizando ultrassom previamente a extração, este trabalho visa reunir as atuais informações relevantes sobre a extração de óleo essencial empregando ultrassom como pré-tratamento. Além disso, aspectos teóricos como os principais fatores que influenciam o desempenho deste método e as vantagens e desvantagens do uso do ultrassom como uma alternativa para melhorar a extração de óleos essenciais de forma mais ambientalmente amigável em comparação com os métodos tradicionais são mostrados. Considerando os estudos disponíveis na literatura sobre a extração de óleos essenciais utilizando ultrassom como pré-tratamento, os melhores resultados obtidos empregam baixas frequências, que variam de 20 a 50kWz e tempos de extração entre 20 a $40 \mathrm{~min}$. A utilização de ultrassom como pré-tratamento possibilita uma redução de tempo de cerca de $70 \%$ em relação à hidrodestilação convencional. Além disso, estas condições permitem um aumento na extração de compostos bioativos e consequentemente melhoram a atividade antioxidante e antimicrobiana dos óleos essenciais obtidos.

Key words: óleo essencial, alimento, extração, ultrassom, química verde.

\section{INTRODUCTION}

The essential oil international market moves a considerable economic portion. Statistics from the United Nations Commodity Trade Statistics Database revealed that, in 2014, importing essential oils generated between $\$ 3,43$ and $\$ 3,91$ billions in exporting. France and United States are the leading countries in imports and exports. Brazil is currently the world's fourth larger exporter of essential oils, mainly the citric, such as orange, lemon and lime (BIZZO \& REZENDE, 2009; COMTRADE, 2014).

In light of the high economic value of essential oils, food, pharmaceutical and fragrance industries have shown interest in this market. Furthermore, their beneficial properties, such as 
the antimicrobial, antioxidant, anti-inflammatory, anticancer and antimutagenic activities as well as the strong and nice flavor of these compounds, have addressed the industries attention (BAKKALI et al., 2008; MIGUEL, 2010; GUIMARÃES et al., 2010; SHAABAN et al., 2012). The use of natural products that present these properties in foods have recently gained prominence, mainly because of their essence as a natural product, reflecting in health benefits for humans in opposition to the synthetic. In this sense, the extraction of these natural compounds from fruits, vegetables and plants has been the target of several studies that aimed to develop new methodologies to extract substances rich in, mainly, antioxidant and antimicrobial activities with suitable yields (FARHAT et al., 2011).

Essential oils are mainly extracted from medicinal and aromatic plants and fruit parts, such as shell and pulp. They are considered a complex mixture of volatile substances. The most valuable compounds are the oxygenated terpenes, since they are highly odoriferous, present more antioxidant activity and stability in comparison to other compounds. As a result, a better quality of essential oil is achieved. Considering that oil quality is related to its chemical composition, the choice of a suitable extraction method is extremely important. The method employed should not influence negatively the composition, avoiding the decomposition of the interest compounds in order to maintain the quality of the final product (BAKKALI et al., 2008; DJOUAHRI et al., 2013).

Use of green technologies that allow the development of methodology bases to prevent negative influences in compositions is an investigation topic in several research areas. Ultrasound is a promising alternative to avoid the use of solvents and reduce the time consumption in essential oil extractions. In this sense, considering the small amount of publications on ultrasonic pretreatment prior to hydrodistillation, this review intended to bring available information together to cover this lack in the literature.

\section{DEVELOPMENT}

\section{Essential oils}

Volatile oils or essential oils are lipophilic, liquid, normally less dense than water and are highly odoriferous substances. The essential oil designation refers to its hydrophobic characteristics and to its similarity to oils in terms of viscosity. The term essential consists of the native essence and specific fragrance of the plant from which the oil is extracted (RAUT \& KARUPPAYIL, 2014).
Antioxidant compounds presented in some essential oils, such as terpenic and phenolic, prevent or delay oxidation processes or even interrupt or delay reactions between peroxyl and hydroxyl radicals (MASTELIC et al., 2008; MIGUEL, 2010; AMORATI et al., 2013). Moreover, essential oils present a great antimicrobial activity, which is attributed to these compounds and their hydrophobic characteristic. This characteristic enables the partition of the compounds in the plasma membranes and mitochondria causing a cell disorder and leading to an increase in the permeability and to a loss of cellular constituents, being more efficient against gram positive bacteria than gram negative bacteria (BURT, 2004; OKOH et al., 2010; VIUDAMARTOS et al., 2011; JAYASENA, 2013). The presence of these substances are generally related to responses to stress conditions and to the defense mechanisms of plants (KOROCH et al., 2007; BAKKALI et al., 2008).

The complexity of the chemical composition of essential oil refers to their activity, mainly to their major constituents. According to some authors, the antioxidant and antimicrobial potential is related to obtainment of extracts with high phenolic compounds and low presence of unsaturated terpenes. Thymol, carvacrol, eugenol, $\alpha$-terpinene and $\gamma$-terpinene are the constituents that present more antioxidant activity (MASTEIC et al., 2008). The existent literature reported an antimicrobial activity that presents, in the majority of compounds, groups of aldehydes, phenols and alcohols. Conversely, the minority of compounds are methyl esters and terpenes hydrocarbons, such as camphene, $\alpha$-terpinene, carvacrol, camphor and caryophyllene oxide (KALEMBA \& KANICKA, 2003; HYLDGAARD et al., 2012). Essential oils are poorly stable in high temperatures. In this sense, during the extraction of these substances by conventional methods, normally using high temperatures, yield losses and degradation reactions are observed, decreasing the product quality (TRANCHIDA et al., 2006).

Antioxidant and antimicrobial activities have made essential oil the target of several investigations, which aim to replace the use of conservatives or even potentiate the antimicrobial activity of substances, such as sodium chloride, sodium nitrite, nitrate and nisin (BURT, 2004). Furthermore, the use of these natural compounds with preservative techniques, such as soft thermic treatment, high pressure hydrostatic and anaerobic packaging, have been the focuses of several studies (BURT, 2004). 


\section{Conventional extraction methods}

Conventional methods employed to

essential oil extraction show many limitations, such as a great consumption of reagents, high-energy costs and mainly high temperature conditions for a long time reflecting in degradation of active compounds and consequently loss of quality. As a result, there is an expanding demand for alternative methods that enable the extraction of essential oil with increased quality in a faster, more efficient, and more economical way, causing less environmental impact.

The extraction of essential oil from plants involved two physical phenomenon: first, the diffusion of essential oil by the cell wall; and second, the dissolution in a medium. The structure glands are very thin being easily destroyed by heat or mechanical action. Conventionally, the methods employed to volatile compounds are hydrodistillation, vapor distillation, vacuum distillation, solvent extraction, cold pressing and supercritical carbon dioxide extraction. The method mainly indicated to essential oil extraction in the Brazilian Pharmacopoeia is the hydrodistillation that consists in boiling the biomass using water (BRAZIL, 2010). In this method, the biomass is immersed into the water and the generated vapor penetrates the vegetal material, opening the pores and releasing oils from the glands. Mixture of water and oil are vaporized, cooled in a condenser and separated by density or by a hygroscopic substance, such as the anhydrous sodium sulfate. (VINATORU et al., 1997). When it comes to essential oil extraction, the use of high temperature conditions can compromise their quality, promoting losses of compounds by thermic and hydrolytic degradations (POURMORTAZAVI et al., 2007).

\section{Alternative extraction methods}

Conventional methods have been applied in the last decades; however, these methods present some disadvantages, as previously mentioned. As a result, a significant increase in investigations on alternative methods to extract efficiently these compounds without high temperature conditions was recently perceived. Development of extraction methods that offer a reduction in time and costs are very interesting to industries. Ultrasound assisted extraction, pressurized liquid extraction, supercritical fluid extraction and microwave assisted extraction have drawn researchers' attention and prompted them to develop methods relatively more advantageous than the conventional (CHEMAT, 2013). The method using ultrasound has been studied by several researchers in order to increase the quality of essential oil and decrease the extraction time and the costs (ROMDHANE \& GOURDON, 2002; PÉREZ-SERRADILHA et al., 2007; CRAVOTTO et al., 2008; PORTO \& DECORTI, 2009; WANG et al., 2010; DJOUAHRI et al., 2013; FILLY et al., 2014).

Extraction mechanisms involved using ultrasound and applications for essential oil

Sonochemistry means the use of ultrasound (acoustic energy) to obtain a chemical reaction and the use of mechanical waves with a frequency rate over than $16 \mathrm{kHz}$. The mechanical waves need a propagation medium where consecutive cycles of compression and rarefaction are present. The ultrasound waves are generated from transducer magnetostrictive or piezoelectric, which are submitted to electric field and some electroelastomechanical deformations, resulting in a conversion from electric to mechanical energy. In this sense, the use of ultrasound in low frequency is employed to extract some compounds mainly through molecular agitation, heating, micro-jets formation and cavitation phenomenon (KRUG, 2010).

Cavitation is the main chemical factor that occurs when ultrasound with low frequency is used. It involves the formation, increase in size and implosive rupture of bubbles in liquid (Figure 1). This phenomenon results from the compression and rarefaction of bubbles, promoting their far apart organization. During these cycles, a progressive increase of cavities up to a critical size occur and a collapse happens. This implosion generate hot spots, high pressure (around 100atm) and average temperatures of $5000^{\circ} \mathrm{C}$ by some seconds (MASON, 1990; MASON, 2002).

Some variables, such as frequency and intensity of ultrasound, viscosity, superficial tension, vapor pressure of the liquid, kind of gases or external pressure, can affect the formation of cavitation bubbles. The frequency is related to the capacity of the bubble cavitation, thus when high frequencies are employed, the cavitation phenomenon is observed since the cycles of compression and rarefaction occur very fast, as in medical ultrasounds. Other important factor is the ultrasound intensity. Increasing the intensity, efficiency decreases as a result of larger and more stable bubbles formation without cavitation (MASON, 1990; MASON, 2002). In addition, high viscosity and superficial tension impairing the formation of cavitation bubbles and using liquids with high vapor pressure and elevated temperatures can affect negatively the collapse intensity. Temperature of the medium is also an important point. High temperatures promote the 


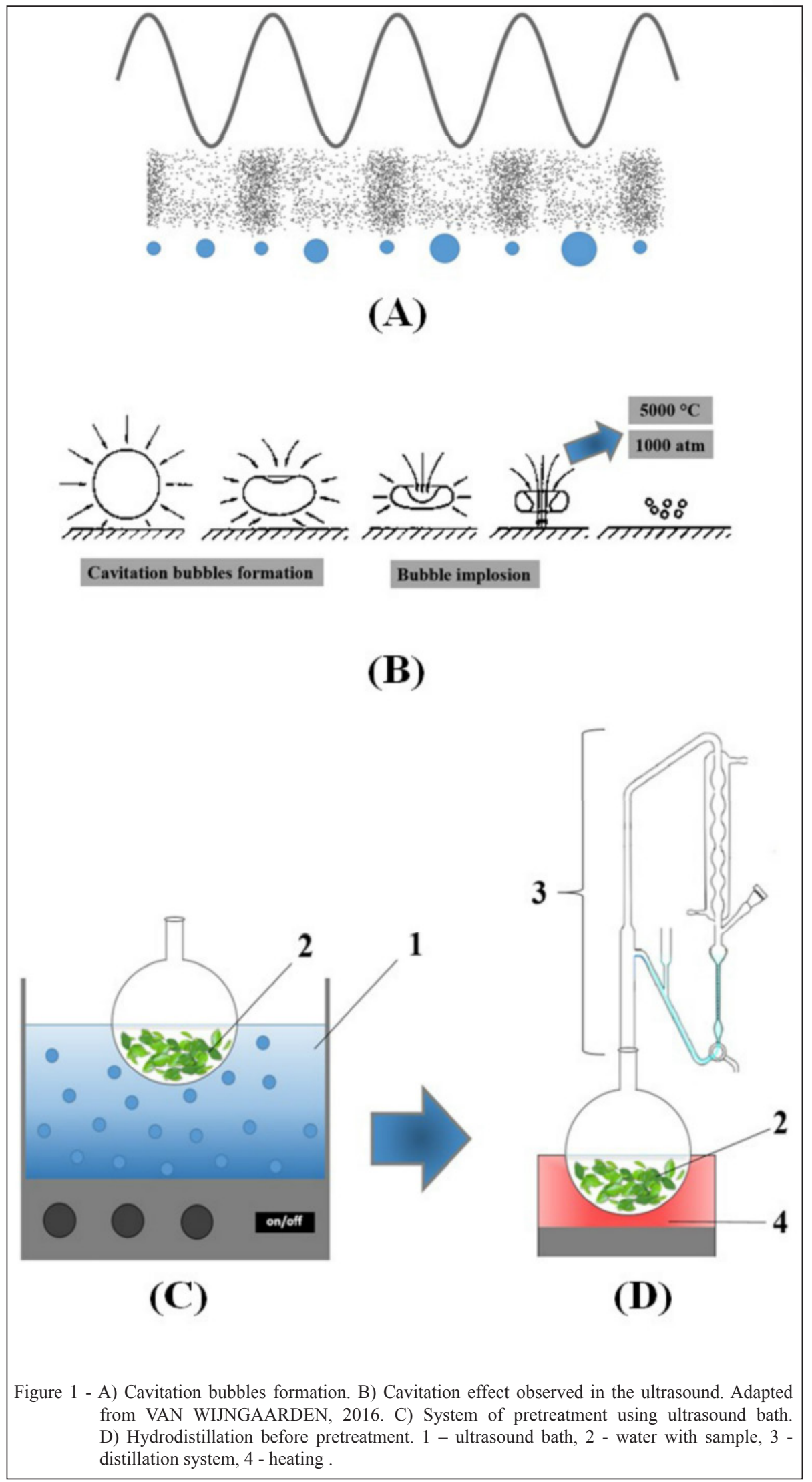

Ciência Rural, v.47, n.9, 2017. 
suppression of the sonochemistry effect, impairing the ultrasound streaming as a consequence of the great amount of bubbles. When external pressure is elevated, the ultrasound efficiency decreases because of the difficulty during the expansion cycle. However, bubble collapse is more intense (KRUG, 2010).

The ultrasound effect depends on changes in the medium, in other words, when cavitation bubbles implode in a solid surface, a distortion of the pressure zone occurs and jets up to $400 \mathrm{~km} \mathrm{~h}^{-1}$ are generated. This high speed enables the removal and rupture of cell membranes or increase their porosity, facilitating the mass transfer from the cell interior (TOMA et al., 2001; VINATORU, 2001). Taking into account the ultrasound phenomenon and the low mechanical resistance of glands cell membranes that contain essential oils, it is possible to extract essential oil efficiently in a low time consumption, since the micro jets formed during cavitation bubbles generated the surface peeling, erosion and cells breakdown (CHEMAT, et al., 2017). According to previous studies, the cavitation phenomenon is observed when ultrasound is used in low frequencies, in which the main factor is the cavitation bubbles. Currently, the employment of ultrasonic pretreatment prior to hydrodistillation has been analyzed in several studies. Methodology consists in the pretreatment of the biomass with water for a further extraction step, as shown in figure 1 (TOMA et al., 2001). Several studies have investigated the ultrasonic pretreatment prior to hydrodistillation step aiming to improve the essential oil quality and decrease the time and energy consumption. These data are presented in table 1 .

Aiming to improve the essential oil quality and verify different extraction methods, some studies evaluated the time of ultrasonic pretreatment prior to hydrodistillation. According to these investigations (Table 1), an increase in the yield was obtained and the effects on the chemical composition were dependent on the evaluated conditions. In general, the use of ultrasound as pretreatment in essential oil extraction decrease by three times (mean average)

Table 1 - Applications of ultrasound (US) as pretreatment after hydrodistillation (HD) of essential oil extraction.

\begin{tabular}{|c|c|c|c|}
\hline Matrix & Experimental conditions & Main results & Reference \\
\hline Thymus vulgaris L. (leaves) & $\begin{array}{l}\text { US bath, } 240 \mathrm{~W}, 40 \mathrm{kHz}, 30^{\circ} \mathrm{C}, 10 \text {, } \\
20,60 \text { and } 120 \mathrm{~min}, 1: 20 \\
\text { (sample:water), } \mathrm{HD} \text { by } 3 \mathrm{~h} . \\
\text { Determination by GC-FID e GC-MS. }\end{array}$ & $\begin{array}{l}\text { Yield increase of } 9 \% \text { with US by } 20 \\
\text { min, density increase with long time, } \\
\text { reduction of p-cimene, carvacrol and } \\
\text { thymol and increase in } \gamma\end{array}$ & KOWALSKI, 2009 \\
\hline Carum carvi L. (seeds) & $\begin{array}{l}\text { US probe, } 25 \mathrm{kHz}, 30 \mathrm{~min}, 1: 10 \\
\text { (sample:water), HD by } 3 \mathrm{~h} . \\
\text { Determination by GC-MS. }\end{array}$ & $\begin{array}{l}\text { Increase of oxygenated compounds, } \\
\text { reduction in } 70 \% \text { of time and } \\
\text { increase in the ration of } \\
\text { carvon/limonene }\end{array}$ & ASSAMI, 2012 \\
\hline $\begin{array}{l}\text { Lavandula intermedia } \\
\text { (flowers) }\end{array}$ & $\begin{array}{c}\text { US probe, } 20 \mathrm{kHz}, 30 \mathrm{~min}, 1: 20 \\
\text { (sample:water), HD by } 30 \mathrm{~min} \text {. } \\
\text { Determination by GC-FID e GC-MS. }\end{array}$ & $\begin{array}{l}\text { Reduction of } 2.5 \text { times the } \\
\text { extraction time and increase the } \\
\text { concentration of major compounds }\end{array}$ & PÉRINO-ISSARTIER, 2013 \\
\hline $\begin{array}{l}\text { Elettaria cardamomum L. } \\
\text { Maton (seeds) }\end{array}$ & $\begin{array}{l}\text { US probe, } 50 \mathrm{kHz}, 20^{\circ} \mathrm{C}, 30 \mathrm{~min} \text {, } \\
20^{\circ} \mathrm{C}, 1: 12.5 \text { (sample:water). } \\
\text { Determination by GC-MS }\end{array}$ & $\begin{array}{c}\text { Yield increase in low time and } \\
\text { increase in the ratio of } \\
\text { monoterpenes } \\
\text { oxygenated/hydrocarbon }\end{array}$ & MORSY, 2015 \\
\hline 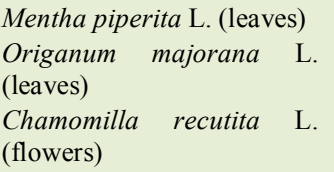 & $\begin{array}{l}\text { US bath, } 240 \mathrm{~W}, 40 \mathrm{kHz}, 30^{\circ} \mathrm{C}, 30 \\
\text { min, } 1: 20 \text { (sample:water), HD by } 3 \\
\text { h. Determination by GC-MS. }\end{array}$ & $\begin{array}{c}\text { Yield increase of } 12 \% \text {, } \\
\text { time reduction in } 3 \text { times, and } \\
\text { essential oils without significantly } \\
\text { changes. }\end{array}$ & KOWALSKI, 2015 \\
\hline Daucus carota (seeds) & $\begin{array}{l}\text { US bath, } 40 \mathrm{kHz}, 20^{\circ} \mathrm{C}, 20 \mathrm{~min}, \\
\text { 1:10 (sample:water), HD by } 3 \mathrm{~h} . \\
\text { Determination by GC-MS. }\end{array}$ & $\begin{array}{l}\text { Reduction time in } 3 \text { times and } \\
\text { increase in the ration of oxygenated } \\
\text { sesquiterpenes/ monoterpenes }\end{array}$ & SMIGIELSK, 2015 \\
\hline $\begin{array}{l}\text { Prangos ferulacea } \text { Lindl. } \\
\text { Satureja macrosiphonia } \\
\text { Bornm. }\end{array}$ & $\begin{array}{l}\text { US bath, } 160 \mathrm{~W}, 35 \mathrm{kHz}, 30^{\circ} \mathrm{C}, 15 \\
\text { min, } 1: 20 \text { (sample:water), } \mathrm{HD} \text { by } 3 \\
\text { h. Determination by GC-MD. }\end{array}$ & $\begin{array}{l}\text { Time reduction in } 2 \text { times, increase } \\
\text { of major compounds extraction and } \\
\text { increase in the antibacterial and } \\
\text { antioxidant activity }\end{array}$ & DAMYEIH, 2016 \\
\hline Lavandula (flowers) & $\begin{array}{c}\text { US probe, } 700 \mathrm{~W}, 20 \mathrm{kHz}, \mathrm{HD} \text { by } 3 \\
\text { h, 1:12 (sample:water). } \\
\text { Determination by GC-MS. }\end{array}$ & $\begin{array}{c}\text { Yield increase of } 10 \% \text { and increase } \\
\text { of linalool and 4-terpineol, increase } \\
\text { of major compounds }\end{array}$ & FILLY, 2016 \\
\hline
\end{tabular}


the time of extraction. Nevertheless, an increase in the rate of bioactive compounds was reported as well as changes in the chemical composition were present, such as the rate of carvon/limonene, providing greater features to apply these extracts as natural antioxidants. Increase in the quality of the essential oil can be attributed to the low level of degradation of thermal compounds (ASSAMI et al., 2012; PINGRET et al., 2014; KOWALSKI et al., 2015). In addition, modifications in the composition are related to the ease release of the essential oils from secretory glands or to transformations of unstable chemical compounds during the ultrasound application (TOMA et al., 2001; PORTO et al., 2009; ASSAMI et al., 2012).

The possibility of increasing the yield, decreasing the time, changing the chemical composition, increasing the extraction of compounds responsible for antioxidant and antimicrobial activities are advantages of the ultrasonic pretreatment prior to hydrodistillation by Clevenger, making this product very valuable to apply in cosmetics, medicines and foods as a natural preservative (TOMA et al., 2001; PORTO et al., 2009; ASSAMI et al., 2012; PINGRET et al., 2014; SMIGIELSKI et al., 2014; MORSY et al., 2015; DAMYEH et al., 2016). Minimal degradation of the chemical compounds relates mainly to the low submission time of plants to heating-, and to an increase in the extraction kinect. This extraction is explained by the fast release of essential oils when ultrasound is previously used, breaking the cell membranes of glands. This phenomenon enables an effective extraction in a considerable shorter time with a better quality in comparison to conventional methods (PINGRET et al., 2014; MORSY, 2015; ).

Routine extractions of essential oils in industries are performed specially by conventional hydrodistillation and, the pre-treatment by ultrasound before hydrodistillationis a very innovative method that can be used in daily industrial scale. In this sense, an industrial ultrasound bath of low frequencies can be employed, reflecting in high throughput of essential oils extraction and consequently greater economic benefits. However, studies should be developed in order to evaluate this approach in large scale because of the lack of information in the literature, specifically for essential oil extraction.

In relation to green aspects, the use of ultrasound combined with hydrodistillation allows the extraction of essential oil with the same amount of biomass and water, but in shortened extraction time (until 3 times) without loss of quality or yield of the final product. So, the energy consumption is lower, reflecting in less pollutants emission, making this method greener than conventional methods. (LI et al., 2013; JACOTET-NAVARRO et al., 2016).

\section{CONCLUSION}

The search for beneficial natural products to health has grown in recent years. The obtainment of antioxidant and antimicrobial substances from natural sources has then gained prominence in several areas, such as food, cosmetic, technological and pharmacological. Considering this scenario, essential oil and extraction methods have become a focus in studies, since some parameters are important to obtain products with suitable quality and yield. In this sense, a concern with methods that employ a considerable amount of reagents, long time and elevated energy consumption has turned alternative methodologies that consider environmental impacts into an interesting and innovative technology to study. Search for alternative methods has considered ultrasound a topic of investigation in recent years. The use of ultrasound as pretreatment, in general, offers some advantages in terms of improvement in the yield, bioactive compounds extraction with effects in the antioxidant and antimicrobial activities, reduction in the thermal degradation of compounds, reduction in time to extract the products, making the essential oil extraction cheaper and environmental friendly. However, the method requires an equipment of ultrasound, which is not used in the conventional method, demanding higher costs and trained professionals. In addition, the mechanical effect of ultrasound is obtained only in low frequencies (below $50 \mathrm{kWh}$, according to previous researches), since higher frequencies may not show good results in relation to structural rupture, impairing the essential oil release. Selection on the best condition to extract essential oil from different plants should be based on the efficiency of extraction, ease of procedure, security, lower costs and time. Considering the previous studies in the literature, the use of low frequencies of ultrasound ranged from 20 to $50 \mathrm{kWz}$ associated with times ranged from 20 to $40 \mathrm{~min}$ results in quality in the extract. In this sense, this review showed that the extraction of essential oils is a very important issue to several areas. It also points out that the use of ultrasound as pretreatment is a very innovative method that can be used in daily industrial scale, replacing conventional methods. 


\section{ACKNOWLEDGEMENTS}

The authors are grateful to Coordenação de Aperfeiçoamento de Pessoal de Nível Superior (CAPES) and Conselho Nacional de Desenvolvimento Científico e Tecnológico (CNPq) for supporting this study.

\section{REFERENCES}

AMORATI, R. et al. Antioxidant activity of essential oils. Journa of Agricultural and Food Chemistry, v.61, p.10835-10847, 2013. Available from: $<$ http://pubs.acs.org/doi/abs/10. 1021/jf403496k>. Accessed: Oct. 09, 2016. doi: 10.1021/jf403496k.

ASSAMI, K. et al. Ultrasound induced intensification and selective extraction of essential oil from Carum carvi L. seeds. Chemical Engineering and Processing: Process Intensification, v.62, p.99-105, 2012. Available from: <http://www.sciencedirect.com/ science/article/pii/ S0255270112001675>. Accessed: Oct. 01, 2016. doi: 10.1016/j.cep.2012.09.003

BAKKALI, F. et al. Biological effects of essential oils - a review. Food and Chemical Toxicology, v.46, p.446-475, 2008. Available from: $<$ http://www.sciencedirect.com/science/article/pii/ S0278691507004541>. Accessed: Sept. 21, 2016. doi: 10.1016/j. fct.2007.09.106

BRAZIL. Farmacopéia brasileira. Brasília. Agência Nacional de Vigilância Sanitária, Brazil, 2010. 745p.

BURT, S. Essential oils: their antibacterial properties and potential applications in foods - a review. International Journal of Food Microbiology, v.94, p.223-253, 2004. Available from: <http:// www.sciencedirect.com/science/article/pii/S0168160504001680>. Accessed: Sept. 23, 2016. doi: 10.1016/j.ijfoodmicro.2004.03.022.

CHEMAT, F.; CRAVOTTO, G. Microwave-assisted Extraction for bioactive compounds. Torino, Italia: Springer, 2013. 237p.

CHEMAT, F. et al. Ultrasound assisted extraction of food and natural products. Mechanisms, techniques, combinations, protocols and applications. A review. Ultrasonics Sonochemistry, v.34, p.540-560, 2017. Available from: <http://www.sciencedirect. com/science/articl e/pii/S1350417716302358>. Accessed: Apr. 19 , 2017. doi: 10.1016/j.ultsonch.2016.06.035.

CRAVOTTO, G. et al. Improved extraction of vegetable oils under high-intensity ultrasound and/or microwaves. Ultrasonics Sonochemistry, v.15, p.898-902, 2008. Available from: <http:// www.sciencedirect.com/science/article/pii/S1350417707001733>. Accessed: Oct. 26, 2016. doi: 10.1016/j.ultsonch.2007.10.009.

DAMYEH, M.S. et al. Ultrasound pretreatment impact on Prangos ferulacea Lind. and Satureja macrosiphonia Bornm. essential oil extraction and comparing their physicochemical and biological properties. Industrial Crops and Products, v.87, p.105-115, 2016. Available from: <http://www.sciencedirect.com/science/ article/pii/S0926669016302424>. Accessed: Oct. 27, 2016. doi: 10.1016/j.indcrop.2016.04.025.

DJOUAHRI, A. et al. Effect of extraction method on chemical composition, antioxidant and anti-inflammatory activities of essential oil from the leaves of Algerian Tetraclinis articulata (Vahl) masters. Industrial Crops and Products, v.44, p.32-36, 2013. Available from: <http://www.sciencedirect.com/science/
article/pii/S0926669012005730>. Accessed: Oct. 18, 2016. doi: 10.1016/j.indcrop.2012.10.021.

FARHAT, A. et al. Microwave steam diffusion for extraction of essential oil from orange peel: Kinetic data, extract's global yield and mechanism. Food Chemistry, v.125, p.255-261, 2011. Available from: $<$ http://www.sciencedirect.com/science/article/pii/ S0308814610009787>. Accessed: Sept. 23, 2016. doi: 10.1016/j. foodchem.2010.07.110

FILLY, A. et al. Solvent-free microwave extraction of essential oil from aromatic herbs: From laboratory to pilot and industrial scale. Food Chemistry, v.150, p.193-198, 2014. Available from: <http:// www.sciencedirect.com/science/article/pii/S0308814613015884>. Accessed: Oct. 19, 2016. doi: 10.1016/j.foodchem.2013.10.139.

GUIMARÃES, R. et al. Contribution of essential oils and phenolics to the antioxidant properties of aromatic plants. Industrial Crops and Products, v.32, p.152-156, 2010. Available from: <http:// www.sciencedirect.com/science/article/pii/S0926669010000907>. Accessed: Oct. 01, 2016. doi: 10.1016/j.indcrop.2010.04.011.

HYLDGAARD, M. et al. Essential oils in food preservation: mode of action, synergies, and interactions with food matrix components. Frontiers in Microbiology, v.3, p.1-24, 2012. Available from: $<$ https://www.ncbi.nlm.nih.gov/pubmed/22291693>. Accessed: Feb. 19, 2017. doi: 10.3389/fmicb.2012.00012.

JACOTET-NAVARRO, M. et al. Towards a "dry" biorefinery without solvents or added water using microwaves and ultrasound for total valorization of fruit and vegetable byproducts. Green Chemistry, v.18, p.3106-3115, 2016. Available from: <http://pubs.rsc.org/en/content/articlelanding/2016/gc/ c5gc02542g\#!divAbstract>. Accessed: May 09, 2017. doi: 10.1039/C5GC02542G

JAYASENA, D.D.; JO, C. Essential oils as potential antimicrobial agents in meat and meat products: a review. Trends in Food Science \& Technology, v.34, p.96-108, 2013. Available from: <http:// www.sciencedirect.com/science/article/pii/S0924224413002033>. Accessed: Sept. 28, 2016. doi: 10.1016/j.tifs.2013.09.002.

KALEMBA, D; KUNICKA, A. Antibacterial and antifungal properties of essential oils. Current Medicinal Chemistry, v.10, p.813-829, 2003. Available: from: <https://www.ncb i.nlm. nih.gov/pubmed/12678685>. Accessed: Feb. 19, 2017. doi: $10.2174 / 0929867033457719$

KOROCH, A.R. et al. Bioactivity of essential oils and their components. Flavours and fragrances. Nova Brunswick: Berger, 2007. Cap.5, p.87-115.

KOWALSKI, R.; WAWRZKOWSKI, J. Effect of ultrasoundassisted maceration on the quality of oil from leaves of thyme Thymus vulgaris L. Flavors and Fragrance Journal, v.26, p.69-74, 2009. Available from: <http://onlinelibrary.wiley.com/ doi/10.1002/ffj.1918/abstract>. Accessed: Nov. 26, 2016. doi: $10.1002 /$ ffj. 1918 .

KOWALSKI, R. et al. Effect of the ultrasound-assisted preliminary maceration on the efficiency of the essential oil distillation from selected herbal raw materials. Ultrasonics Sonochemistry, v.24, p.214-220, 2015. Available from: <http://www.sciencedirect.com/ science/article/pii/S1350417714003745>. Accessed: Oct. 28, 2016. doi: 10.1016/j.ultsonch.2014.12.008. 
LI, Y. et al. Green ultrasound-assisted extraction of carotenoids based on the bio-refinery concept using sunflower as an alternative solvent. Ultrasonics Sonochemistry, v.20, p.12-18, 2013. Available from: $<$ http://www.sciencedirect.com/science/article/pii/ S1350417712001447>. Accessed: May 09, 2017. doi: 10.1016/j. ultsonch.2012.07.005.

MASON, T.J. Sonochemistry: the uses of ultrasound in chemistry. London: The Royal Society of Chemistry, 1990. 149p.

MASON, T.J.; LORIMER, J.P. Applied sonochemitry: the uses of ultrasound in chemistry and processing. Weinheim: Wiley-VCH Verlag GmbH, 2002. 311p.

MASTELIĆ, J. et al. Comparative study on the antioxidant and biological activities of carvacrol, thymol, and eugenol derivatives. Journal of Agricultural and Food Chemistry, v.56, p.3989-3996, 2008. Available from: <http://pubs.acs.org/ doi/abs/10.1021/jf073272v>. Accessed: Sept. 16, 2016. doi: $10.1021 / \mathrm{jf073272v}$.

MIGUEL, M.G. Antioxidant and anti-inflammatory activities of essential oils: a short review. Molecules, v.15, p.92529287, 2010. Available from: <http://www.mdpi.com/14203049/15/12/9252>. Accessed: Oct. 16, 2016. doi: 10.3390/ molecules 15129252 .

MORSY, N.F.S. A short extraction time of high quality hydrodistillation cardamom (Elletaria cardamomum L. Maton) essential oil using ultrasound as a pretreatment. Industrial Crops and Products, v.65, p.287-292, 2015. Available from: $<$ http://www.sciencedirect.com/science/article/pii/ S0926669014007778>. Accessed: Oct. 26, 2016. doi: 10.1016/j.indcrop.2014.12.012.

$\mathrm{OKOH}$, O.O. et al. Comparative evaluation of the antibacterial activities of the essential oils of Rosmarinus officinalis L. obtained by hydrodistillation and solvent free microwave extraction methods. Food Chemistry, v.120, p.308-312, 2010. Available from: <http://www.sciencedirect.com/science/article/ pii/S0308814609011443>. Accessed: Oct. 27, 2016. doi: 10.1016/j.foodchem.2009.09.084.

PÉREZ-SERRADILLA, J.A. et al. Simultaneous microwaveassisted solid-liquid extraction of polar and nonpolar compounds from alperujo. Analytica Chimica Acta, v.602, p.82-88, 2007. Available from: $<$ http://www.sciencedirect.com/science/article/pii/ S0003267007015140>. Accessed: Oct. 16, 2016. doi: 10.1016/j. aca.2007.09.008.

PÉRINO-ISSARTIER, S. et al. A comparison of essential oils obtained from lavandin via different extraction processes: ultrasound, microwave, turbohydrodistillation, stem and hydrodistillation. Journal of Chromatography A, v.1305, p.4147, 2013. Available from: <http://www.sciencedirect.com/science/ article/pii/S0021967313010443>. Accessed: Nov. 16, 2016. doi: 10.1016/j.chroma.2013.07.024.

PINGRET, D. et al. An improved ultrasound clevenger for extraction of essential oils. Food Analytical Methods, v.7 p.9-12, 2014. Available from: <http://link.springer.com/article /10.1007/ s12161-013-9581-0>. Accessed: Nov. 01, 2016. doi: 10.1007/ s12161-013-9581-0.

PORTO, C.; DECORTI, D. Ultrasound-assisted extraction coupled with under vacuum distillation of flavour compounds from spearmint (carvone-rich) plants: comparison with conventional hydrodistillation. Ultrasonics Sonochemistry, v.16, p.795-799, 2009. Available from: <http://www.sciencedirect.com/science/ article/pii/S1350417709000480>. Accessed: Oct. 27, 2016. doi: 10.1016/j.ultsonch.2009.03.010.

POURMORTAZAVI, S.M.; HAJIMIRSADEGHI, S.S. Supercritical fluid extraction in plant essential and volatile oil analysis. Journal of Chromatography A, v.1163, p.2-24, 2007. Available from: <http:// www.sciencedirect.com/science/article/pii/S0021967307010229>. Accessed: Oct. 29, 2016. doi: 10.1016/j.chroma.2007.06.021.

RAUT, J.S.; KARUPPAYIL, S.M. A status review on the medicinal properties of essential oils. Industrial Crops and Products, v.62, p.250-264, 2014. Available from: <http://www.sciencedirect.com/ science/article/pii/S0926669014005196>. Accessed: Sept. 29, 2016. doi: 10.1016/j.indcrop.2014.05.055.

ROMDHANE, M.; GOURDON, C. Investigation in solid-liquid extraction: influence of ultrasound. Chemical Engineering Journal, v.87, p.11-19, 2002. Available from: <http://www. sciencedirect.com/science/article/pii/S1385894701002066>. Accessed: Oct. 27, 2016. doi: 10.1016/S1385-8947(01)00206-6.

SHAABAN, H.A.E. et al. Bioactivity of essential oils and their volatile aroma components: review. Journal of Essential Oil Research, v.24, p.203-212, 2012. Available from: <http://www. tandfonline.com/doi/abs/10.1080/10412905.2012.659528>. Accessed: Oct. 27, 2016. doi: 10.1080/10412905.2012.659528.

SMIGIELSKI, K.B. et al. The effect of ultrasound-assisted maceration of the bioactivity, chemical composition and yield of essential oil from waste carrot seeds (Daucus carota). Journal of Essential Oil Bearing Plants, v.17, p.1075-1086, 2014. Available from: <http://onlinelibrary.wiley.com/doi/10.1111/j.1472765X.2004.01605.x/abstract>. Accessed: Oct. 27, 2016. doi: 10.1080/0972060X.2014.931253.

TOMA, M. et al. Investigation of the effects of ultrasound on vegetal tissues during solvent extraction. Ultrasonics Sonochemistry, v.8, p.137-142, 2001. Available from: <http://www.sciencedirect. com/science/article/pii/S135041770000033X>. Accessed: Oct. 27, 2016. doi: 10.1016/S1350-4177(00)00033-X

TRANCHIDA, P.Q. et al. High-throughput analysis of bergamot essential oil by fast solid-phase microextraction-capillary gas chromatography-flame ionization detection. Journal of Chromatography, v.1103, p.162-165, 2006. Available from: $<$ http:// www.sciencedirect.com /science/article/pii/S0021967305022570>. Accessed: Oct. 30, 2016. doi: 10.1016/j.chroma.2005.11.073.

VAN WIJNGAARDEN, L. Mechanisms of collapsing cavitation bubbles. Ultrasonics Sonochemistry, v.29, p.524-527, 2016. Available from: <http://www.sciencedirect.com/ science/article/ pii/S1350417715000863> . Accessed: Jan. 20, 2017. doi: 10.1016/j. ultsonch.2015.04.006.

VINATORU, M.T. et al. The use of ultrasound for the extraction of bioactive principles from plant materials. Ultrasonics Sonochemistry, v.4, p.135-139, 1997. Available from: <http:// www.sciencedirect.com/science/article/pii/S1350417797832075>. Accessed: Oct. 28, 2016. doi: 10.1016/S1350-4177(97)83207-5.

VINATORU, M. An overview of the ultrasonically assisted extraction of bioactive principles from herbs. Ultrasonics Sonochemistry, v.8, p.303-313, 2001. Available from: 
$<$ http://www.sciencedirect.com/science/article/pii/ S1350417701000712>. Accessed: Oct. 27, 2016. doi: 10.1016/ S1350-4177(01)00071-2.

VIUDA-MARTOS, $M$. et al. In vitro antioxidant and antibacterial activities of essentials oils obtained from Egyptian aromatic plants. Food Control, v.22, p.1715-1722, 2011. Available from: <http://www.sciencedirect.com/science/article/
pii/S0956713511001307>. Accessed: Oct. 26, 2016. doi: 10.1016/j.foodcont.2011.04.003.

WANG, H.W. et al. Comparison of microwave assisted and conventional hydrodistillation in the extraction of essential oil from mango (Mangifera indica L.) flowers. Molecules, v.15, p.7715-7723, 2010. Available from: <http://www.mdpi.com/1420-3049/15/11/7715> Accessed: Oct. 19, 2016. doi: 10.3390/molecules15117715. 